\title{
Impact of Financial Ratios on Non-Performing Loans of Publicly Traded Commercial Banks in Bangladesh
}

\author{
Md. Ataur Rahman ${ }^{1}$, Md. Asaduzzaman ${ }^{2} \&$ Md. Shakhaowat Hossin ${ }^{1}$ \\ ${ }^{1}$ Department of Finance and Banking, Begum Rokeya University, Rangpur, Bangladesh \\ ${ }^{2}$ School of Business Administration, East Delta University, Chittagong, Bangladesh \\ Correspondence: Md. Ataur Rahman, Lecturer, Department of Finance and Banking, Begum Rokeya University, \\ Rangpur-5400, Bangladesh.
}

Received: January 1, 2017

Accepted: January 18, 2017

Online Published: January 22, 2017

doi:10.5430/ijfr.v8n1p181

URL: http://dx.doi.org/10.5430/ijfr.v8n1p181

\begin{abstract}
This study investigates the influences of a set of financial ratios on non-performing loans and to show to what extent of listed commercial banks in Bangladesh. In this study, we applied an econometric model to find out correlations among financial ratios and a sample of 96 observations has been analyzed from 20 banks out of 30 listed commercial banks during 2010-2015. This paper mostly agrees with the existing literature that, credit-deposit ratio, net interest margin have a positive influence on the non-performing loans and capital adequacy ratio, return on assets have a negative influence on the non-performing loans. This research also reveals that, sensitive sector's loan, priority sector's loan have significant positive influence on the non-performing loans and unsecured loans, profit per employee, investment deposit ratio have significant negative impact on gross non-performing loan. The findings of this research would help commercial banks to maintain standard financial ratios in order to improve their loan qualities and it would be beneficial to the central bank to examine its existing policy in banking supervision relating to the ratios of regulatory requirements like capital adequacy ratio the banks shall maintain.
\end{abstract}

Keywords: non-performing loans, financial ratios, correlation, commercial banks

\section{Introduction}

The economic development of a country and constancy of banking system are perpetually interrelated. International experience demonstrated that if Non-Performing Loans (NPLs) are not managed properly, it will lead to banking failures and countrywide financial vulnerability. Credit management is thus essential to ensure a sound financial system and possibly provides an early alarm to regulatory authorities of banking system (Prasanna et al., 2014). Muniappan (2002) argued that a bank with high level of NPLs is enforced to incur costs on non-performing loans that not only strike at portability but also at the capital adequacy of a bank, and in consequence, the bank faces complexities in increasing capital resources. Bonin and Huang (2001) also stated that the probability of banking crises increases if financial risk is not reduced quickly. Such crises not only force to lower living standards but also can abolish many of the achievements of economic transformation overnight. Private commercial banks are the leading financial institutions in most economies more specifically in Bangladesh.

NPLs refer to loans or advances whose credit quality has declined such that full collection of principal and/or interest in reference to contractual repayment conditions of the loan or advances is due and uncollected for 90 (ninety) consecutive days or more away from the scheduled payment date or maturity. They are known as non-performing because the loan ceases to "perform" or produce income for the bank (Adhikary, 2006).

Existing literature finds that, competition augmented banks' credit risk, i.e. distressing their loan portfolios in terms of bad loan screening procedures and relaxing borrowing criteria (Jeong and Jung, 2013). Thus, NPLs are expected to raise extremely in the forthcoming years, distressing the liquidity and profitability of banks and thus the financial stability of the banking systems (Makri et al., 2014).

The Central Bank forces the commercial banks to place provision against classified loans so as to protect the public who deposits their savings with commercial banks. It is also argued that the NPLs are one of the most important causes of the economic stagnation troubles and if the NPLs remain increasing and are constantly rolled over, the 
resources may be confined in unprofitable sectors; thus, hampering the economic growth and spoiling the economic efficiency.

Adequate literatures be present on bank specific factors and macroeconomic factors of NPLs and problem loans (e.g. Dash and Kabra, 2010; Rajan and Dhal, 2003; Berger and DeYoung, 1997; Demirguc-Kunt and Huizinga, 1999; Messai and Jouni, 2013; Mukherjee, P., 2003) but a small number about financial determinants of NPLs hampering performance of private commercial banks in Bangladesh. However, contrary to the huge majority of the existing literature, to the best of our knowledge, this research is the first empirical study to show the effect of financial ratios on NPLs and to show to what extent in the context of publicly traded commercial banks in Bangladesh. This study also examines relationships between non-performing loans and some ratios of regulatory requirements of central bank of the country.

Given the above discussion, banks should control and modify their credit improvement policy relating to influencing variables to have lower non-performing loan ratio (Filip et al., 2014) and it is necessary to identify the influences of financial ratios on NPLs to ensure economic development of the country which is the major motivation of this research.

The rest of the paper is organized as follows. Section 2 reviews related literature and formulates the hypothesis relating to NPLs and financial ratios. Section 3 describes the data set and presents econometric methodology used in this study. Section 4 presents findings and analysis of the results. Finally section 5 summarizes our concluding remarks and offers further research area relating to non-performing loans.

\section{Literature Review and Hypothesis}

Many studies on the causes of bank failures have found that institutions facing financial distress have higher proportions of non-performing loans prior to failure and that asset quality demonstrates a statistically significant forecaster of insolvency (Berger and DeYoung, 1997).

According to the research by Havrilesky and Boorman (1976), interest on loans contributed significantly to interest income of commercial banks. Reed and Gill (1989) pointed out that usually $85 \%$ of commercial banks income is contributed by interest on loans. Loans therefore represented the majority of bank's assets (Saunders and Cornett, 2005). Lending is not an easy task for banks because it created a big problem which is called NPLs (Upal, 2009). Due to the nature of their business, commercial banks exposed themselves to the risks of default from borrowers and NPLs are closely associated with banking crises (Waweru and Kalami, 2009).

Greenidge and Grosvenor (2010) argued that the magnitude of NPLs is a key element in the initiation and progression of financial and banking crises. Guy (2011) argued that NPLs have been widely used as a measure of asset quality among lending institutions and is often related with failures and financial crises in both the developed and developing world. Despite ongoing efforts to control bank lending activities, NPLs are still a major concern for both international and local regulators (Boudriga et al, 2009). According to Podpiera and Weill (2008) bank specific factors selected by each bank like cost efficiency, capitalization, activity diversification, performance and credit growth have an impact on the progression of NPLs. Louzis et al., (2012) used bank-specific variables and macroeconomic factors, simultaneously, to examine the determinants of NPLs in the Greek banking sector.

Our study tries to examine the effect of various bank specific financial ratios on gross non-performing loan. We assume that there is a relationship between bank specific financial ratios and aggregate NPL of the bank.

\subsection{Credit-Deposit Ratio}

The credit-deposit ratio is affected by the operational strategy of a bank's management. Credit growth is considered one of the most important causes of problem loans (Jimenez and Saurian, 2006). A rapid expansion of credit may not be a problem by itself, but such expansion leads to poor screening and lending to borrowers of inferior quality (Sinkey and Greenwalt, 1991). It is expected that increases in credit-deposit ratio would affect problem loans positively.

\subsection{Ratio of Unsecured Loans to Total Loans}

It is that portion of loans on which a borrower is not required to furnish any asset as collateral against the loan. Banks usually ask for collateral to hedge against defaults. According to Yadav (2013), the unsecured loans attracted more interest than the secured loans because the risk of unsecured loan is larger to the lender. Hence, the effect of the unsecured loans of banks on their NPLs is likely to be positive. 


\subsection{Ratio of Sensitive Sector's Loan to Total Loan}

The sensitive sector is composed of commercial real estate, the commodity sector and capital markets. The total of sensitive sector lending to gross advance ratio is taken as the measure of the sensitive sector ratio. A major portion of the exposure to the sensitive sector is contribution by the real estate sector. It is expected that increases loans in sensitive sector would affect problem loans positively.

\subsection{Ratio of Priority Sector Loans to Total Loans}

The ratio of priority sector lending to total bank credit can be taken as a measure of the priority sector loan ratio of the bank. Priority Sector refers to those sectors of the economy which may not get timely and adequate credit in the absence of this special consideration. It refers to lending to few specific sectors like agriculture, micro or small enterprises.

\subsection{Profit per Employee}

It is an important measure of the management efficiency of banks. It can be argued that bank employees have a strong role in maintaining asset quality. It is their ability to appraise loan proposals or to monitor the loan accounts after disbursements that may ensure better control over the occurrences of NPLs. It is assumed that profit per employee is negatively related to the aggregate LPLs.

\subsection{Capital Adequacy Ratio}

One of the examined financial factors is the capital adequacy ratio. It measures the risk that a bank can undertake. Capital adequacy ratio is calculated by adding tier 1 capital to tier 2 capital and dividing by risk weighted assets which is guided by Basel accord. Generally, capital adequacy ratios widely used in similar studies are not clear whether they affect positively or negatively to the aggregate NPLs (Sinkey and Greenawlat 1991). According to Mukherjee (2003), the presence of large amount of NPLs is responsible for the decline in the profit margin of many banks.

\subsection{Net Interest Margin}

Empirical evidence suggested that there is a positive relationship between interest margin and aggregate NPLs. Such a positive relationship is expected because a high proportion of problem loans may cause banks to increase their interest margin to compensate for possible default risks (Angbazo, 1997; Demirgc-Kunt and Huizinga, 1999; Mendes and Abree, 2003; Carbo and Rodriguez, 2007).

\subsection{Return on Assets}

It is an important indicator of the performance of a bank since it determines the profitability of the bank based on its assets. Growing NPLs slow down interest earning capacity due to their non-recognition of interest and, on the other hand, provision for NPLs increases interest suspense but reduces realized profits. In the context of emerging market economics, the findings of Godlewski (2004) indicated that there is a negative impact of return on assets on the level of non-performing loans.

\subsection{Investment-Deposit Ratio}

Total investment includes all the long term and short term investments like loans, advances, investment in stock markets and any other approved securities by central bank. The ratio between the total investments and total deposits of a bank is called the investment-deposit ratio. Banks' profitability is related to the risk-taking behavior of banks. As high profitable banks have fewer incentives to engage in high-risk activities. Thus, investment-deposit ratio has negative effect on the level of NPLs.

\subsection{Hypothesis}

The present study formulates and tests the following alternative hypotheses concerning a set of mentioned financial ratios and gross NPL ratio:

$H_{1}$ : Credit-deposit ratio is positively related to the gross NPL ratio.

$\mathrm{H}_{2}$ : Unsecured loan to total loan ratio is positively related to the gross NPL ratio.

$H_{3}$ : Sensitive sector's loan to total loan ratio is positively related to the gross NPL ratio.

H4: Priority sector's loan to total loan ratio is positively related to the gross NPL ratio.

H5: Profit per employee is negatively related to the gross NPL ratio.

H6: Capital adequacy ratio is negatively related to the gross NPL ratio. 
H7: Net interest margin to total assets is positively related to the gross NPL ratio.

H8: Return on asset is negatively related to the gross NPL ratio.

H9: Investment-deposit ratio is negatively related to the gross NPL ratio.

\section{Data and Econometric Methodology}

\subsection{Data and Variables Characterization}

A sample of 96 secondary observations has been collected from audited financial statements of 20 banks out of 30 publicly traded commercial banks during 2010-2015. To make sure valid estimates of the measures, an observation is incorporated only when it satisfies certain criteria like availability and completeness of data. Financial ratios that can affect the gross non-performing loan (dependent variable) are identified as independent variables and shown in the following Table 1.

Table 1. Presentation of dependent and independent variables

\begin{tabular}{cccc}
\hline Symbol & Explanation & Calculation Method & Expected Sign \\
\hline GNPL & Gross NPL ratio & Aggregate NPL/Total loans & $(+)$ \\
CDR & Credit-deposit ratio & Total loans/Total deposits & $(+)$ \\
UNS & Unsecured loans ratio & Unsecured loan/Total loans & $(+)$ \\
SEN & Sensitive sector's loan ratio & Sensitive sector's loans/Total loans & $(+)$ \\
PSL & Priority sector's loan ratio & Priority sector's loans/Total loans & $(+)$ \\
PPE & Profit per employee ratio & Net profit/No. of employees & $(-)$ \\
CAR & Capital adequacy ratio & Capital/Risk weighted assets & $(-)$ \\
NIM & Net interest margin ratio & Net Interest Margin/Total assets & $(+)$ \\
ROA & Return on assets ratio & Net profit/Total assets & $(-)$ \\
IDR & Investment deposit ratio & Investment/Total deposits & $(-)$ \\
\hline
\end{tabular}

Source: Compiled by authors

\subsection{Specification of Econometric Model}

The multiple linear regression model used in this study is as follows:

$\mathrm{GNPL}_{\text {it }}=\alpha+\beta_{1} \mathrm{CDR}_{\text {it }}+\beta_{2} \mathrm{UNS}_{\text {it }}+\beta_{3} \mathrm{SEN}_{\text {it }}+\beta_{4} \mathrm{PSL}_{\text {it }}+\beta_{5} \mathrm{PPE}_{\mathrm{it}}+\beta_{6} \mathrm{CAR}_{\mathrm{it}}+\beta_{7} \mathrm{NIM}_{\text {it }}+\beta_{8} \mathrm{ROA}_{\text {it }}+\beta_{9} \mathrm{IDR}_{\text {it }}+\varepsilon_{\text {it }}$ Where, $\alpha$ is constant;

$\beta_{1}$ to $\beta_{9}=$ Coefficient of determinants of gross NPL ratio;

i (number of banks) $=1,2, \ldots 20$;

$\mathrm{t}($ time-interval $)=1,2, \ldots .6$;

$\varepsilon$ is error term.

\section{Findings and Analysis}

\subsection{Descriptive Statistics}

The descriptive statistics of the variables used in this empirical analysis are presented in Table 2. The mean value of GNPL is around $3 \%$ with a standard deviation of $1.40 \%$. In addition, the variable GNPL record a rather low variability as the value range from $1.05 \%$ to $6.39 \%$. The mean value of CDR is $81.22 \%$ with a standard deviation of $9.99 \%$, minimum value of CDR is $44 \%$ and maximum is $108.26 \%$. Variable UNS present a minimum of $0.01 \%$ and a maximum of $100.96 \%$ with a standard deviation of $33.80 \%$. Variables SEN and PSL extends from $0.04 \%$ to $58.31 \%$ and $0.15 \%$ to $192.56 \%$ respectively. The mean value of PPE is Tk. $1,106,163$ with a standard deviation of 5.38\%. 
Table 2. Descriptive statistics of variables used in the Econometric Model

\begin{tabular}{cccccc}
\hline Variables & Observations & Mean & Min & Max & Std. Deviation \\
\hline GNPL & 96 & 2.99 & 1.05 & 6.39 & 1.40 \\
CDR & 96 & 81.22 & 44 & 108.26 & 9.99 \\
UNS & 96 & 26.10 & 0.01 & 100.96 & 33.80 \\
SEN & 96 & 4.29 & 0.04 & 58.31 & 8.32 \\
PSL & 96 & 62.42 & 0.15 & 192.56 & 47.48 \\
PPE & 96 & 1106163.37 & 118458.18 & 2492291.88 & 5.38 \\
CAR & 96 & 65.24 & -8.68 & 1211.63 & 193.01 \\
NIM & 96 & 5.41 & 0.00 & 69.88 & 10.92 \\
ROA & 96 & 1.74 & 0.02 & 12.60 & 1.99 \\
IDR & 96 & 24.48 & 1.33 & 93.80 & 20.02 \\
\hline
\end{tabular}

Source: Results obtained (SPSS output) by the authors

Variable CAR, presents a very high variability, since its minimum value stands at $-8.68 \%$ and maximum at $1211.63 \%$. The mean value of NIM is around $5.41 \%$ with a standard deviation of $10.92 \%$ but it records a minimum value approximately $0.00 \%$. ROA ranges from $0.02 \%$ to $12.60 \%$ with low disparity about $2 \%$. Finally, variable IDR ranges from $1.33 \%$ to $93.80 \%$ with a standard deviation of $20.02 \%$.

\subsection{Correlation Matrix}

The correlation matrix of financial ratios used in this study is presented in Table 3. GNPL has positive correlation with CDR $(\mathrm{r}=.163)$, SEN $(\mathrm{r}=.13)$, PSL $(\mathrm{r}=.288)$, PPE $(\mathrm{r}=.034)$ and NIM $(\mathrm{r}=.119$. Where GNPL has negative correlation with UNS $(r=-.398), \operatorname{CAR}(r=-.251), \operatorname{ROA}(r=-.115)$ and $\operatorname{IDR}(r=-.079)$.

Table 3. Correlation matrix of financial ratios

\begin{tabular}{|c|c|c|c|c|c|c|c|c|c|c|}
\hline & CDR & UNS & SEN & PSL & PPE & CAR & NIM & ROA & IDR & GNPL \\
\hline$\overline{\mathrm{CDR}}$ & 1 & & & & & & & & & \\
\hline UNS & -.007 & 1 & & & & & & & & \\
\hline SEN & -.035 & $.231^{*}$ & 1 & & & & & & & \\
\hline PSL & $-.411^{* *}$ & $-.238^{*}$ & .035 & 1 & & & & & & \\
\hline PPE & $.485^{* *}$ & -.106 & .030 & $-.239^{*}$ & 1 & & & & & \\
\hline CAR & -.124 & -.176 & .072 & .057 & $-.354^{* *}$ & 1 & & & & \\
\hline NIM & -.072 & -.165 & .052 & -.037 & .142 & .014 & 1 & & & \\
\hline ROA & .120 & .009 & .083 & -.183 & $.469^{* *}$ & -.093 & $.470^{* *}$ & 1 & & \\
\hline IDR & .164 & $-.222^{*}$ & -.017 & -.070 & -.048 & .027 & -.155 & -.130 & 1 & \\
\hline GNPL & .163 & $-.398^{* *}$ & .130 & $.288^{* *}$ & .034 & $-.251^{*}$ & .119 & -.115 & -.079 & 1 \\
\hline
\end{tabular}

**. Correlation is significant at the 0.01 level (2-tailed).

*. Correlation is significant at the 0.05 level (2-tailed).

Source: Results obtained (SPSS output) by the authors

\subsection{Model Testing}

The adjusted R-square value of the following Table 4 is 0.504 , which means that $50.4 \%$ variations of the dependent variable (GNPL) is due to the independent variables (financial ratios). Coefficient of determination(R-square) value is 0.551 , which shows the highest percentage value that the independent variables explain $55.10 \%$ changes of gross non-performing loan. The coefficient of correlation $(\mathrm{R})$ of the model is 0.742 , which states that there is a strong 
relationship between the financial ratios (independent variables) and gross non-performing loans (dependent variable).

Table 4. Model summary**

\begin{tabular}{cccc}
\hline $\mathrm{R}$ & $\mathrm{R}^{2}$ & Adjusted $\mathrm{R}^{2}$ & Std. Error of the Estimate \\
\hline $0.742 *$ & 0.551 & 0.504 & 0.98828 \\
\hline * Predictors: (Constant), IDR, SEN, PPE, NIM, PSL, CAR, UNS, CDR, ROA &
\end{tabular}

*. Predictors: (Constant), IDR, SEN, PPE, NIM, PSL, CAR, UNS, CDR, ROA

**. Dependent Variable: GNPL

In the following Table 5, the value of F statistic is 11.72 and P-value is 0.000 which is less than $5 \%$. This indicates that the overall model is statistically significant.

Table 5. ANOVA**

\begin{tabular}{lccccc}
\hline & Sum of Squares & df & Mean Square & F & P-Value \\
\hline Regression & 103.012 & 9 & 11.446 & 11.72 & \multirow{2}{*}{$.000^{*}$} \\
Residual & 83.996 & 87 & .977 & & \\
\hline Total & 187.008 & 96 & & & \\
\hline
\end{tabular}

*. Predictors: (Constant), IDR, SEN, PPE, NIM, PSL, CAR, UNS, CDR, ROA

**. Dependent Variable: GNPL

It further implies that credit-deposit ratio; unsecured loans ratio; sensitive sector's loan ratio; priority sector's loan ratio; profit per employee ratio; capital adequacy ratio; net interest margin ratio; return on assets ratio and investment deposit ratio have impact on gross non-performing loan.

Table 6. Coefficients*

\begin{tabular}{|c|c|c|c|c|c|}
\hline \multirow{2}{*}{$\begin{array}{l}\text { Independent } \\
\text { variables }\end{array}$} & \multicolumn{2}{|c|}{ Unstandardized Coefficients } & \multirow{2}{*}{$\begin{array}{c}\text { Standardized } \\
\text { Coefficients }(\beta)\end{array}$} & \multirow{2}{*}{$\mathrm{t}$} & \multirow{2}{*}{ Sig. } \\
\hline & $\beta$ & Std. Error & & & \\
\hline (Constant) & -.147 & 1.013 & - & -.145 & .885 \\
\hline $\mathrm{CDR}$ & .060 & .013 & .430 & 4.688 & .000 \\
\hline UNS & -.023 & .004 & -.557 & -6.357 & .000 \\
\hline SEN & .052 & .013 & .308 & 4.022 & .000 \\
\hline PSL & .003 & .001 & .236 & 2.784 & .007 \\
\hline PPE & -.001 & .000 & -.315 & -3.015 & .003 \\
\hline CAR & -.003 & .000 & -.450 & -5.508 & .000 \\
\hline NIM & .016 & .011 & .122 & 1.426 & .158 \\
\hline ROA & -.090 & .067 & -.128 & -1.355 & .179 \\
\hline IDR & -.018 & .005 & -.252 & -3.209 & .002 \\
\hline
\end{tabular}

*. Dependent Variable: GNPL

Since the hypothesis $\left(\mathrm{H}_{1-9}\right)$ was developed based on the financial ratios listed in Table 1 where the significant value of seven ratios (CDR, UNS, SEN, PSL, PPE, CAR and IDR) are less than 0.05; as a result null hypotheses $\left(\mathrm{H}_{0}\right)$ are rejected and alternative hypotheses $\left(\mathrm{H}_{1-6,9}\right)$ are accepted. But in contrast the significant value of NIM and ROA are more then 0.05; as a result null hypotheses $\left(\mathrm{H}_{0}\right)$ are accepted and alternative hypotheses $\left(\mathrm{H}_{7-8}\right)$ are rejected. Thus, the GNPL is predicted with about $50.4 \%$ explanatory power by the following model:

$\mathrm{GNPL}_{\text {it }}=-.147+.060 \mathrm{CDR}_{\text {it }}-.023 \mathrm{UNS}_{\text {it }}+.052 \mathrm{SEN}_{\mathrm{it}}+.003 \mathrm{PSL}_{\mathrm{it}}-.001 \mathrm{PPE}_{\mathrm{it}}-.003 \mathrm{CAR}_{\text {it }}+.016 \mathrm{NIM}_{\text {it }}-.090$ $\mathrm{ROA}_{\text {it }}-.018 \mathrm{IDR}_{\text {it }}+\varepsilon_{\text {it }}$ 


\subsection{Analysis of Findings}

As per corporate finance theory, higher credit-deposit ratio; sensitive sector's loan ratio and priority sector's loan ratio will lead to higher possibility of Gross NPL ratio of Banking sector. The results of our study are similar to the results of the studies conducted by Sinkey and Greenwalt (1991). Again higher the unsecured loans ratio; profit per employee ratio; capital adequacy ratio; and investment deposit ratio lower the gross non-performing loan.

Our results related to relationship between a gross non-performing loan and unsecured loans ratio are differ to those found in previous studies (Yadav , 2013). However, analysis related to relationship between gross non-performing loan with profit per employee ratio; capital adequacy ratio; and investment deposit ratio agree with the studies of Sinkey and Greenawlat (1991), Mukherjee (2003). Summary results of tested hypotheses are exposed in the following Table 7.

Table 7. Summary results of tested hypotheses

\begin{tabular}{cccccc}
\hline Hypotheses & Variables & Expected Signs & Results Found & Accepted/Rejected & Sig.(at 5\%) \\
\hline $\mathrm{H}_{1}$ & CDR & $(+)$ & $(+)$ & Accepted & Yes \\
$\mathrm{H}_{2}$ & UNS & $(+)$ & $(-)$ & Accepted & Yes \\
$\mathrm{H}_{3}$ & SEN & $(+)$ & $(+)$ & Accepted & Yes \\
$\mathrm{H}_{4}$ & PSL & $(+)$ & $(+)$ & Accepted & Yes \\
$\mathrm{H}_{5}$ & PPE & $(-)$ & $(-)$ & Accepted & Yes \\
$\mathrm{H}_{6}$ & CAR & $(-)$ & $(-)$ & Accepted & Yes \\
$\mathrm{H}_{7}$ & NIM & $(+)$ & $(+)$ & Rejected & Not \\
$\mathrm{H}_{8}$ & ROA & $(-)$ & $(-)$ & Rejected & Not \\
$\mathrm{H}_{9}$ & IDR & $(-)$ & $(-)$ & Accepted & Yes \\
\hline
\end{tabular}

\section{Conclusion}

In this study, we applied an econometric model that facilitated to identify the influences of financial ratios on non-performing loans of listed commercial banks in Bangladesh. A sample of 96 observations has been analyzed during 2010-2015 and we found strong correlations between gross non-performing loans and various bank-specific financial ratios. This paper shows the cause-effect relationship between the financial ratios (independent variables) and gross non-performing loans (dependent variable) in Bangladesh.

This study demonstrated that credit-deposit ratio, sensitive sector's loan, priority sector's loan, net interest margin have a positive influence on the non-performing loans and unsecured loans, profit per employee, capital adequacy ratio, return on assets, investment deposit ratio have a negative impact on gross non-performing loan. We found that all financial ratios used in this study have significant impact on NPLs except net interest margin and return on equity. Future research should pay more attention to investigate credit assessment; credit monitoring; collateralized lending; borrowers' credit culture and lending interest rates those have powerful influences on non-performing loans.

\section{References}

Adhikary, B.K. (2006). Nonperforming loans in the banking sector of Bangladesh: realities and challenges. Bangladesh Institute of Bank Management, 75-95.

Angbazo, L. (1997). Commercial Bank Net Interest Margins, Default Risk, Interest-Rate Risk and Off-Balance Sheet Banking. Journal of Banking and Finance, 21(1), 55-87. https://doi.org/10.1016/S0378-4266(96)00025-8

Berger, A.N., \& DeYoung, R. (1997). Problem loans and cost efficiency in commercial banks. Journal of Banking and Finance, 21(6), 849-870. https://doi.org/10.1016/S0378-4266(97)00003-4

Bonin, J.P., \& Huang, Y. (2001). Dealing with the bad loans of the Chinese banks. Journal of Asian Economics, 12(2), 197-214. https://doi.org/10.1016/S1049-0078(01)00082-3

Boudriga A., Taktak, N.B., \& Jellouli, S. (2009). Banking supervision and non-performing loans: a cross- country analysis. Journal of Financial Economic Policy, 1(4), 286-318. https://doi.org/10.1108/17576380911050043

Carbo V.S., \& Rodriguez, F.F. (2007). The Determinants of Bank Margins in European Banking. Journal of Banking and Finance, 31(7), 2043-2063. https://doi.org/10.1016/j.jbankfin.2006.06.017 
Dash, M., \& Kabra, G. (2010). The determinants of non-performing assets in Indian commercial bank: An econometric study. Middle Eastern Finance and Economics, 7(2), 94-106.

Demirguc-Kunt, A., \& Huizinga, H. (1999). Determinants of Commercial Bank Interest Margins and Profitability: Some International Evidence. World Economic Review, 13(2), 379-408. https://doi.org/10.1093/wber/13.2.379

Filip, B.F. (2014). Non-performing loans-dimension of the non-quality of bank lending/loans and their specific connections. Theoretical and Applied Economics, 5(594), 127-146.

Godlewski, C.J. (2004). Capital regulation and credit risk taking: Empirical evidence from banks in emerging market economics, Economics Working Paper Archive at WUSTL, 2004.

Greenidge, K., \& Grosvenor, T. (2010). Forecasting non-performing loans in Barbados. Journal of Business, Finance and Economics in Emerging Economies, 5(1), 80-107.

Guy, K., \& Lowe, S. (2011). Non-performing loans and bank stability in Barbados. Economic Review, 37(1), 77-82.

Havrilesky, T.M., \& Boorman, J.T. (1976). Current issues in monetary theory and policy (2nd ed.).

Jeong, S., \& Jung, H. (2013). Bank Wholesale Funding and Credit Procyclicality: Evidence from Korea. Panoeconomicus, 60(5), 615-631. https://doi.org/10.2298/PAN1305615J

Jimenez, G., \& Saurina, J. (2006). Credit Cycles, Credit Risk, and Prudential Regulation. International Journal of Central Banking, 2(1), 65-98.

Louzis, D., Vouldis, A., \& Metaxas, V. (2012). Macroeconomic and bank-specific determinants of non- performing loans in Greece: A comparative study of mortgage, business and consumer loan portfolios. Journal of Banking \& Finance, 36(4), 1012-1027. https://doi.org/10.1016/j.jbankfin.2011.10.012

Marki, V., Tsagkanos, A., \& Bellas A. (2014). Determinants of Non-Performing Loans: The Case of Eurozone. Panoeconomicus, 61(2), 193-206. https://doi.org/10.2298/PAN1402193M

Mendes, V., \& Abree, M. (2003). Do Macro-Financial Variables Matter for European Bank Interest Margins and Profitability?. In EcoMod2003-International Conference on PolicyModeling. Global Economic Modeling Network.

Messai, A.S., \& Jouni, F. (2013). Micro and Macro Determinants of Non-performing Loans. International Journal of Economic and Financial Issues, 3(4), 852-860.

Mukherjee, P. (2003). Dealing with NPA's: Lessons from International Experience. Money \& Finance, 12(12), 64-90.

Muniappan, G.P. (2002). The NPA Overhang-Magnitude, Solutions, Legal Reforms. Reserve Bank of India Bulletin, 18-19.

Podpiera, J., \& Weill, L. (2008). Bad luck or bad management? Emerging banking market experience. Journal of Financial Stability, 4(2), 135-148. https://doi.org/10.1016/j.jfs.2008.01.005

Prasanna, P.K., Thenmozhi, M., \& Rana, N. (2014). Determinants of non-performing advances in Indian banking system. Banks and Bank Systems, 9(2), 65-77.

Rajan, R., \& Dhal, S.C. (2003). Non-performing loans and terms of credit of public sector banks in India: An empirical assessment. Reserve Bank of India Occasional Papers, 24(3), 81-121.

Reed, E.W., \& Gill, E.K. (1989). Commercial Banking (4th ed.). Prentice Hall, New Jersey, USA.

Saunders and Cornett. (2005). Financial Institution Management, McGraw Hill Publishing.

Sinky, J.F., \& Greenwalt, M. (1991). Loan-loss experience and risk-taking behavior at large commercial banks. Journal of Financial Services Research, 5(2), 43-59. https://doi.org/10.1007/BF00127083

Uppal, R.K. (2009). Priority sector advances: Trends, issues and strategies. Journal of Accounting and Taxation, 1(5), 79-89.

Waweru, N., \& Kalani, V.M. (2009). Commercial banking crises in Kenya: Causes and remedies. African Journal of Accounting, Economics, Finance and Banking Research, 4(4), 12-33.

Yadav, J.R. (2013). Credit Is Inevitable In Banking: A Case Study Of Premier Bank On Credit Appraisal and Assessment. Journal of Business Management and Social Sciences Research, 2(7), 20-29. 